Book Chapter

\title{
Performance in Accelerated Laboratory Tests of Oil Heat Treated 16-Year-Old Acacia mangium
}

Razak Wahab ${ }^{1}$, Illya N Syazwanie $\mathrm{AM}^{2}$, Hashim W Samsi ${ }^{3}$, Mohamad Saiful Sulaiman ${ }^{1}$, Ros Syazmini Mohd Ghani ${ }^{1}$ and Nasihah Mokhtar ${ }^{1}$

${ }^{1}$ University College of Technology Sarawak, Malaysia

${ }^{2}$ Universiti Malaysia Kelantan (UMK), Malaysia

${ }^{3}$ Forest Research Institute Malaysia (FRIM), Malaysia

*Corresponding Author: Razak Wahab, University College of Technology Sarawak, 96000 Sibu, Sarawak, Malaysia

Published May 20, 2020

This Book Chapter is a republication of an article published by Razak Wahab, et al. at Journal of Agricultural Science in May 2017. (R. Wahab, I. N. S. Ahmad Mazalan, M. T. Mustafa, A. R. Mojiol, M. S. Rasat. Improvement in Durability of Oil Heat Treated 16-Year-Old Acacia mangium in Laboratory Tests. Journal of Agricultural Science; Vol. 9, No. 6; 2017.)

How to cite this book chapter: Razak Wahab, Illya $\mathrm{N}$ Syazwanie AM, Hashim W Samsi, Mohamad Saiful Sulaiman, Ros Syazmini Mohd Ghani, Nasihah Mokhtar. Performance in Accelerated Laboratory Tests of Oil Heat Treated 16-Year-Old Acacia mangium. In: João Silva Dias, editor. Prime Archives in Agricultural Research. Hyderabad, India: Vide Leaf. 2020.

(C) The Author(s) 2020. This article is distributed under the terms of the Creative Commons Attribution 4.0 International License(http://creativecommons.org/licenses/by/4.0/), which permits unrestricted use, distribution, and reproduction in any medium, provided the original work is properly cited. 


\section{Abstract}

Performance of the durability of oil heat-treated 16-year-old Acacia mangium through accelerated laboratory tests were studied. A. mangium logs of known age harvested and segregated into the bottom, middle, and top portions. These were oil-heat treated in a tank with oil palm oil as a heating medium at temperatures 180,200 and $220^{\circ} \mathrm{C}$ for the duration of 30,60 and 90 minutes. The wood samples dried and grounded into sawdust were air-dried again before undergoing tests. An accelerated 12 weeks of laboratory durability studies conducted on the treated A. mangium. Fungi of Pycnoporus sanguineus, Gloeophyllum trabeum and Coriolus versicolors inoculated on the woods. Untreated samples used as controls. The results showed that the durability of the wood increases with an increase in temperature and duration of the treatment. The hot oil-treated samples could reduce the attack of G. trabeum from $5.02 \%, 4.41 \%$ and $4.38 \%$ in the control samples to $0.54-4.55 \%, 0.91-4.41 \%$ and 1.08 $4.38 \%$ at the bottom, middle and top portions, respectively. The attack of $C$. versicolors reduced from $11.48 \%, 14.27 \%$ and $15.68 \%$ in the control samples to $1.87-10.19 \%, 3.10-12.69$ and $4.78-15.10 \%$ at the bottom, middle and top portions, respectively. However, the attacked of $P$. sanguineus were less effective with $31.42 \%, 18.24 \%$ and $10.53 \%$ in control samples to $3.71-10.18 \%, 5.74-14.59 \%$ and $4.37-17.08 \%$ at the bottom, middle and top portions, respectively. Massive colonization of mycelia occurs in vessels of the untreated A. mangium wood in comparison to the oil heat-treated wood observed through the scanning electron microscope.

\section{Keywords}

Acacia mangium; Durability; Fungi Inoculation; Oil Heat Treatment; Scanning Electron Microscope

\section{Introduction}

Ease of growth and adaptability has made Acacia mangium one of the most popular plantation species in Malaysia. This fast wood growing species, however, has some disadvantage in 
which the wood contains a high proportion of juvenile wood and poorly developed heartwood particularly at the ages between 14 to 18 -year-old [1]. It has wide growth rings that produce lowdensity wood which exhibited inferior mechanical properties. The durability of the wood becomes weak due to these problems resulting in the wood being attacked by bio-deteriorating agents [2]. The wood of $A$. mangium needs treatment to enhance its properties and durability. The oil heat treatment process can be applied to improve A. mangium durability [3,4]. The heat treatment is one of the wood modification processes used in the wood industry compared to other processes [3]. This treatment is considered an environmental-friendly process it does not uses chemicals $[5,6]$.

\section{Materials and Methodology Tree Harvesting}

Three (3) defects free 16-year-old Acacia mangium trees harvested from Batu Melintang, in Kelantan. The tree selected based on its excellent form, long straight trunk, decay-free and with minimum branches. The age of the trees were determined measuring their diameter at breast height $(\mathrm{DBH})$ and the tree height. The DBH of the harvested A. mangium were $30 \mathrm{~cm}$ with tree height of $12 \mathrm{~m}$. The tree felled using a chainsaw and segregated into the bottom, middle and top portions. The logs then transported to Universiti Malaysia Kelantan (UMK) for the subsequent process.

\section{Sample Preparation}

The woods containing both heartwood and softwood cut into sized $30 \mathrm{~cm}(\mathrm{~L}) \times 10 \mathrm{~cm}(\mathrm{~W}) \times 2.5 \mathrm{~cm}(\mathrm{~T})$ using a chainsaw and a table saw.

\section{Oil Heat Treatment Process}

The wood was oil heat-treated in a stainless steel tank using palm oil as the heating medium (Figure 1). The treatment uses three (3) different temperatures $180^{\circ} \mathrm{C}, 200^{\circ} \mathrm{C}$ and $220^{\circ} \mathrm{C}$ and 
three (3) treatment durations 30, 60 and 90 minutes. Three replicates of woods used for each treatment. Altogether 81 wood samples of sizes $30 \mathrm{~cm} \times 10 \mathrm{~cm} \times 2.5 \mathrm{~cm}$ were treated. Method outlines by Izran et al., [7]; Izyan et al.,[5]; Rafidah, [8]; Razak et al., [9] used in the studies. The wood then removed from the tank after each treatment period ended. Excessive oil on the surface of the sample wiped with a clean cloth as steps to prevent excessive oil from entering the wood tissue. All the samples were then cooled down and stored in the conditioning chamber at $25 \pm 2^{\circ} \mathrm{C}$, and relative humidity $(\mathrm{RH})$ of $65 \pm 5 \%$ before undergoing the testing procedure. Once the moisture contents of the wood reach $12 \%$, they were taken out for resizing and tested for basic density and 12 weeks accelerated laboratory durability tests.

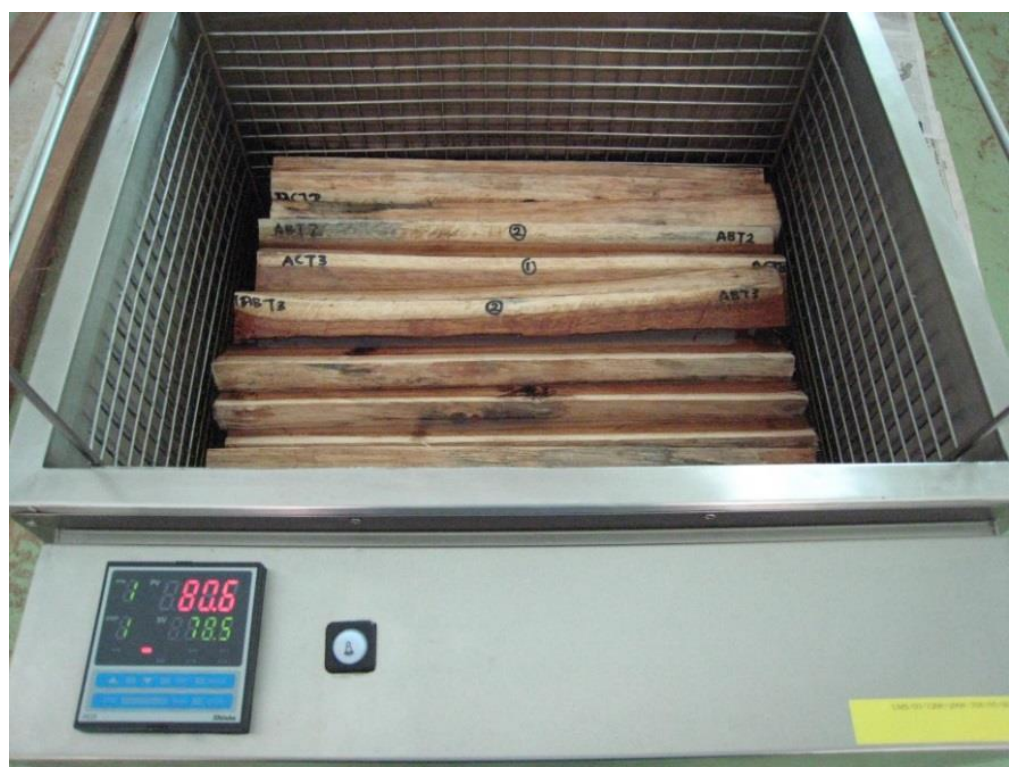

Figure 1: Wood blocks of Acacia hybrid (ca. $55 \times 10 \times 3 \mathrm{~cm})$ soaked into palm oil in a heatable tank to test treatment effects on wood durability.

\section{Density}

Determination of the density of each sample tests conducted according to ISO 3131-1975 standard (Wood: Determination of 
Moisture Content for Physical and Mechanical Tests). The samples of treated and untreated prepared into a size $2 \mathrm{~cm} \times 2$ $\mathrm{cm} \times 2 \mathrm{~cm}$. Then, samples weighed by using the analytical balance, and initial volumes (length $\mathrm{x}$ width $\mathrm{x}$ thickness) of wood measured by using a digital vernier calliper. The samples were then dried in the oven at $103 \pm 2^{\circ} \mathrm{C}$ at least for 24 hours or until the moisture reached $12 \%$. Before weighing the samples to get their final weight, all the samples kept in the desiccators for 15 minutes. After that, the final weight and volumes of samples were measured and recorded.

\section{Durability Test for Treated and Untreated Acacia mangium}

Durability testing against three (3) wood-decaying fungi (Pycnoporus sanguineus, Gloeophyllum trabeum, and Coriolus versicolors) has been conducted to compare the strength of wood before and after the heat-treatment process. The duration of this durability test was 12 weeks, and the standard used in this testing based on the American Wood Preservatives Associations Standard [10] - M10-77 (Standard Method of Testing Wood Preservatives from Soil-Block Culture).

\section{Preparation of Culture Media}

The cultured media that used in this study was Potato Dextrose Agar (PDA) that supplies the nutrient for fungi to growth as represented in Figure 2.15 g of PDA was weighed and put into $250 \mathrm{ml}$ Duran bottle. The agar dissolved in distilled water. Then, PDA agar had been sterile by using an autoclaved machine at 15 psi for 20 minutes at $120^{\circ} \mathrm{C}$. The agar was then poured into a petri dish, sterilized Duran bottle and left to be cool. The culture media that prepared in a petri dish used for inoculation of pure fungal culture whiles the media in Duran bottle were for durability test. Culture media prepared in Duran bottle should be left about $45^{\circ}$ to increase the surface of media. 

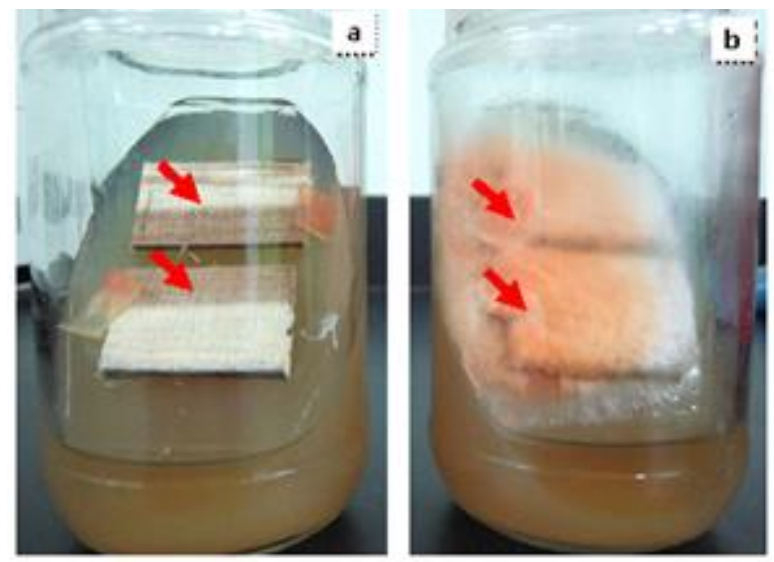

Figure 2: Culture media (MEA) with feeder strips of Acacia hybrid woods and mycelial plugs of the test fungi, $P$. sanguineus (arrows) in $250 \mathrm{ml}$ Duran bottle (a) was fully covered by mycelia after 3 weeks incubation (b) at $26.7^{\circ} \mathrm{C}$ and $70 \% \mathrm{RH}$ in darkness.

\section{Preparation of Test Blocks}

Sterilized samples sized $2.5 \mathrm{~cm} \times 2.5 \mathrm{~cm} \times 0.9 \mathrm{~cm}$ were used for durability test. Each wood samples were wrapped with aluminium foils and autoclaved at 15 psi for 20 minutes. After cooling and dried in laminar flow, the samples aseptically placed onto the culture of decay fungi by using the scalpel.

\section{Inoculation of Fungi}

The fungi $P$. sanguineus, $G$. trabeum, and $C$. versicolors used in this study obtained from the Forest Research Institute of Malaysia (FRIM). The inoculation process conducted in a laminar flow and cleaned by using the $75 \%$ ethanol. The apparatus used were all sterile. Fungi were placed upside down on the media in the Duran bottle. These done properly as not to damage the fungi. The bottles stored in an incubator set at $37^{\circ} \mathrm{C}$ and left for 12 weeks for the fungi to grow. $P$. sanguineus and $C$. versicolor were the white-rot fungi. The illustrated of the process were represent in Figure 3 (a, b, c). 
Prime Archives in Agricultural Research

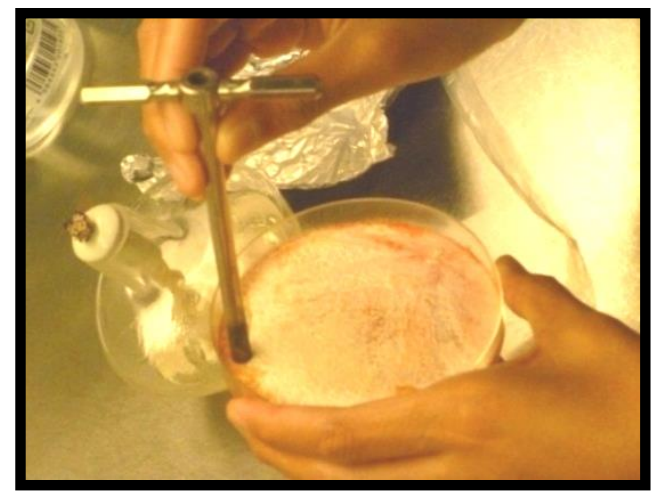

(A)

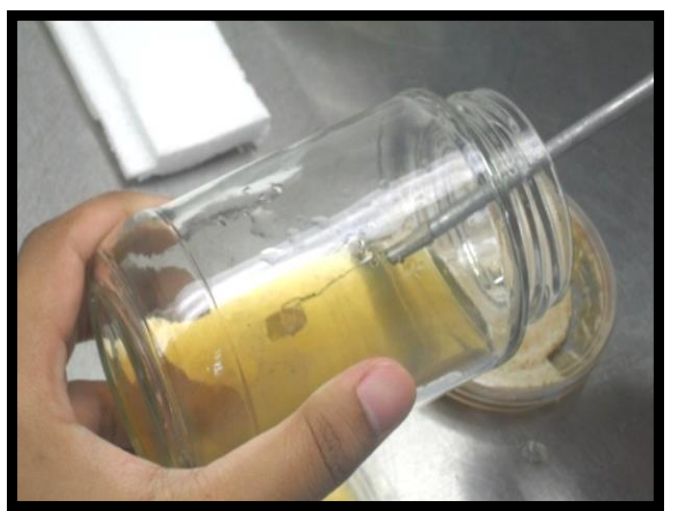

(B)

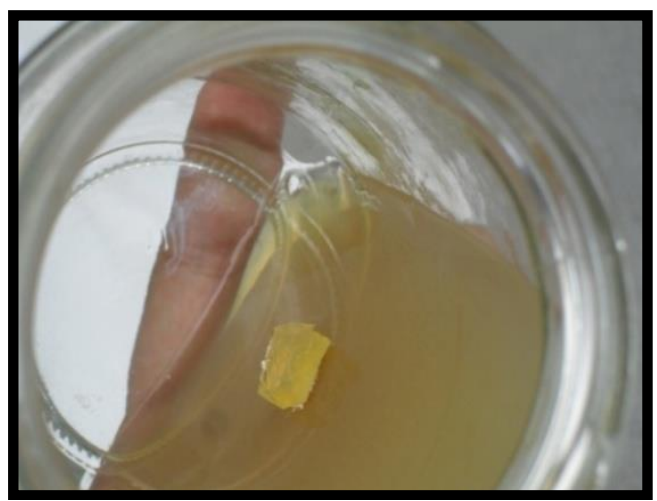

(C)

Figure 3: An inoculation process represented on a, b, and c, respectively; (a) fungi were taken using a borer (b) upside down fungi onto new media (c) fungi on the new media. 


\section{Measurement of Weight Loss}

After 12 weeks, the A. mangium wood blocks removed from the bottled. The samples cleaned by using the scalpel and brush to remove mycelium. Then, all the samples were put into the oven at $60 \pm 5^{\circ} \mathrm{C}$ until the blocks reached its constant weight.

\section{Micromorphology of Colonized Acacia mangium}

After 12 weeks of exposure, the samples of A. mangium cleaned from mycelia by using a brush. Then, the samples were cut into sized $0.3 \mathrm{~cm} \times 0.3 \mathrm{~cm} \times 0.3 \mathrm{~cm}$. The structure of these samples analyzed by scanning electron microscopy (SEM) for hyphal colonization of the woods.

\section{Results and Discussion Density}

Table 1 shows the results for density for each sample under different temperature and duration of treatment at $12 \% \mathrm{MC}$. The untreated wood used as a control. The density at the bottom and middle portions were $0.53 \mathrm{~g} / \mathrm{cm}^{3}$ respectively compared to the top portion $0.52 \mathrm{~g} / \mathrm{cm}^{3}$.

Table 1 showed the density of treated samples increased when treated at 180 and $200^{\circ} \mathrm{C}$ for 30 to 90 minutes. The densities decrease in values after treated at $220^{\circ} \mathrm{C}$ for 60 and 90 minutes. All samples taken at the bottom, middle and top portions exhibited the same trends. The increased in the wood density might be due to the oil that able to penetrate into the cell wall and influence the overall total weight of the sample [11] and resulted in the thickening of the cell wall [12]. The density of wood then started to decrease when treated at high temperature for a long duration of time. These might be due to changes in the wood structure after the treatment as the results of the removal of wax, resin, and others that occur during the treatment [13]. The removal of those substances from the wood structure decreases the density of wood that can slightly reduce the strength of wood. 
Prime Archives in Agricultural Research

Table 1: Mean values of Acacia mangium's density at 12\% moisture content.

\begin{tabular}{|l|l|l|l|l|}
\hline \multirow{2}{*}{$\begin{array}{l}\text { Temperature } \\
\left({ }^{\circ} \mathrm{C}\right)\end{array}$} & Treatment & \multicolumn{4}{|l|}{ Density $\left(\mathrm{g} / \mathrm{cm}^{-3}\right)$} & \\
\hline & duration $(\mathrm{min})$ & Bottom & Middle & Top \\
\hline $0($ Control $)$ & $0($ Control $)$ & 0.53 & 0.53 & 0.52 \\
\hline & 30 & 0.55 & 0.54 & 0.53 \\
& & $(+3.78)$ & $(+1.89)$ & $(+1.92)$ \\
\hline 180 & 60 & 0.54 & 0.54 & 0.53 \\
& & $(+1.89)$ & $(+1.89)$ & $(+1.92)$ \\
\hline & 90 & 0.54 & 0.54 & 0.53 \\
& & $(+1.89)$ & $(+1.89)$ & $(+1.92)$ \\
\hline & 30 & 0.58 & 0.55 & 0.53 \\
& & $(+9.43)$ & $(+3.77)$ & $(+1.92)$ \\
\hline 200 & 60 & 0.57 & 0.54 & 0.54 \\
& & $(+7.55)$ & $(+1.89)$ & $(+3.85)$ \\
\hline & 90 & 0.54 & 0.52 & 0.53 \\
& & $(+1.89)$ & $(+1.89)$ & $(+1.92)$ \\
\hline & 30 & 0.54 & 0.54 & 0.53 \\
& & $(+1.89)$ & $(+1.89)$ & $(+1.92)$ \\
\hline 220 & 60 & 0.53 & 0.53 & 0.52 \\
& & $(0.00)$ & $(0.00)$ & $(0.00)$ \\
\hline & 90 & 0.53 & 0.53 & 0.52 \\
& & $(0.00)$ & $(0.00)$ & $(0.00)$ \\
\hline
\end{tabular}

Note: ()$=\%$ change from control

\section{Durability of Acacia mangium Wood}

The results in Table 2, showed the mean weight loss of $A$. mangium after exposed to the tests fungi. The fungi attack dropped when the temperatures and treatment duration increases as highlighted in Figure 4. This results proved that the oil-heat treatment process could apply to reduce the fungal attack of $A$. mangium woods. The oil-heat treatment increased the durability of $A$. mangium wood in all the portions. The top portions of $A$. mangium experienced the highest weight loss when exposed to all the fungi. The weight loss was $17.08 \%$ when exposed to $P$. sanguineus, $15.20 \%$ to $C$. versicolor and $5.72 \%$ to G. trabeum at temperature $180^{\circ} \mathrm{C}$ for 30 minutes. The lowest was $3.71 \%$ when exposed to $P$. sanguineus, $1.87 \%$ to $C$. versicolor and $0.54 \%$ to G. trabeum at temperature $220^{\circ} \mathrm{C}$ for 90 minutes for all bottom samples. The weight loss of samples taken from the middle portions showed values in between the bottom and top portions. 

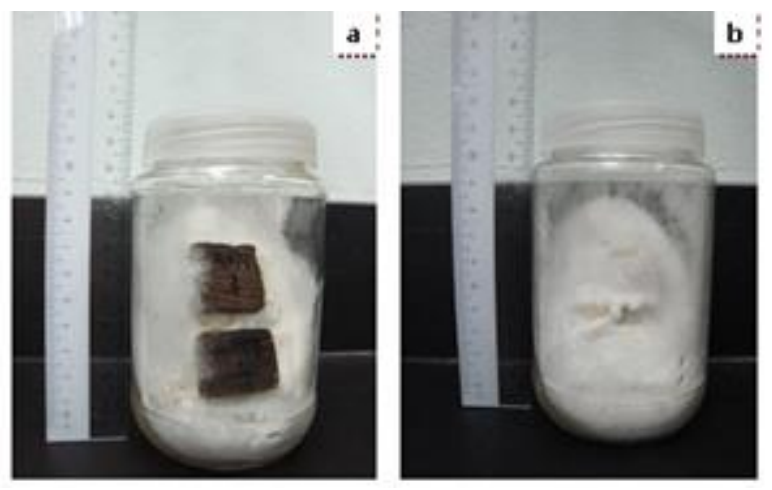

Figure 4: Oil-heat treated and untreated of Acacia hybrid wood blocks ( $c a .2 .5$ x $2.5 \times 0.9 \mathrm{~cm})$ were exposed to the decay fungi $(C$. versicolor; a), and the mycelium (arrow) was covered the woodblocks after 12 weeks testing period (b).

The same results also obtained in the middle and bottom portions for the wood exposed to these three fungi. In the middle portions, the highest weight loss obtained from the wood that undergoes treatment one which is $14.59 \%$ for $P$. sanguineus, $12.69 \%$ for $C$. versicolor and $4.41 \%$ for $G$. trabeum. All the samples in treatment one had been exposed to the fungi after being treated at $180^{\circ} \mathrm{C}$ for 30 minutes. The lowest weight loss in the middle portion resulted from the wood that is treated in treatment 9 (T9) which are $5.74 \%$ ( $P$. sanguineus), 3.10\% ( $C$. versicolor) and $0.91 \%$ ( $G$. trabeum). While the lowest weight loss in the bottom portion is $3.71 \%$ ( $P$. sanguineus), $1.87 \%$ ( $C$. versicolor) and $0.54 \%$ (G. trabeum) that found in wood samples that treat at $220^{\circ} \mathrm{C}$ for 90 minutes.

The fungal attack, according to the fungi type and portions illustrated in Figures 5, 6, and 3, respectively presents wood durability against $P$. sanguineus, $C$. versicolor, and $G$. trabeum. Oil heat-treated $A$. mangium shows decreasing in overall of fungal attack. The oil-heat treatment had changed the components of wood. At a certain temperature and duration, the wood components (cellulose, hemicelluloses, and lignin) degraded at a different level. The degradation of those components depends on the temperature and duration of the heating process and wood species (Callum, 2006). This 
modification in the wood makes them more resistance to the fungi attack.

The untreated $A$. mangium experiences the highest weight loss by the $P$. sanguineus, which is $10.53 \%-18.73 \%$ followed by $C$. versicolor (11.48\%-15.69\%) and G. trabeum (5.02\%-5.72). A. mangium wood at bottom portions possesses the highest resistance against fungi attack compared to the top and middle portions. These is due to the high density of the wood at the bottom compared to the other portions [14]. The treatment is effective in controlling $G$. trabeum attacking the A. mangium woods. The attack of G. trabeum reduced from $5.72 \%$ (top), $5.22 \%$ (middle) and $5.02 \%$ (bottom) in control samples to $1.08 \%-4.38 \%, 0.91 \%-4.41 \%$, and $0.54 \%-4.55 \%$ at top, middle and bottom respectively. The attacks by $C$. versicolor reduced from $15.69 \%, 14.27 \%$, and $11.48 \%$ in the controlled samples to $4.78 \%-15.20 \%, 3.10 \%-12.69 \%$, and $1.87 \%-10.19 \%$ at the top, middle and bottom portions. The treatment, however, was least effective to control the $P$. sanguineus attacks as the weight loss were $10.53 \%, 18.24 \%$, and $18.73 \%$ in control samples to $3.71 \%$ $10.18 \%, 5.74 \%-14.59 \%$, and $4.37 \%-17.08 \%$ at the bottom, middle, and top portions.

The oil-heat treatment proved effective in enhancing the durability of A. mangium wood $[9,11]$. The decreasing weight loss of A. mangium's wood by the fungi, however, are dependent on the temperature and duration of treatment. The decay fungi need suitable moisture and temperature to growth [15]. The white-rot fungi decomposed all the structural component of wood, especially lignin. It also has a complete cellulose complex that can degrade the lignin content in wood [15]. When the lignin had degraded after treatment given, the wood durability could increase because it would decrease the fungus attack since the lack of wood component [16]. The brown rot fungi used in this study is $G$. trabeum which attack the wood and decrease the weight loss of wood. These is because it decomposes the carbohydrates which are hemicelluloses and cellulose that obtained in the wood [15]. The decreasing of weight loss is between $40 \%$ and $50 \%$ in untreated samples to $36 \%$ and $15 \%$ after 12 weeks exposure to the G. trabeum and C. versicolor. 
Prime Archives in Agricultural Research

Table 2: Mean weight loss of Acacia mangium.

\begin{tabular}{|l|l|l|l|}
\hline Treatment & P. sanguineus & C. versicolor & G. trabeum \\
\hline Top Portion & & & \\
\hline Control samples & 18.73 & 15.69 & 5.72 \\
\hline $\mathrm{T} 1\left(180^{\circ} \mathrm{C} / 30 \mathrm{~min}\right)$ & $17.08(8.81)$ & $15.20(3.12)$ & $4.38(23.43)$ \\
\hline $\mathrm{T} 2\left(180^{\circ} \mathrm{C} / 60 \mathrm{~min}\right)$ & $15.42(17.67)$ & $15.08(3.89)$ & $3.36(41.26)$ \\
\hline $\mathrm{T} 3\left(180^{\circ} \mathrm{C} / 90 \mathrm{~min}\right)$ & $13.67(27.02)$ & $12.86(8.04)$ & $3.36(41.26)$ \\
\hline $\mathrm{T} 4\left(200^{\circ} \mathrm{C} / 30 \mathrm{~min}\right)$ & $14.87(20.61)$ & $11.18(28.74)$ & $3.65(36.19)$ \\
\hline $\mathrm{T} 5\left(200^{\circ} \mathrm{C} / 60 \mathrm{~min}\right)$ & $13.66(27.07)$ & $9.48(39.58)$ & $3.53(38.29)$ \\
\hline $\mathrm{T} 6\left(200^{\circ} \mathrm{C} / 90 \mathrm{~min}\right)$ & $13.31(28.94)$ & $8.77(44.10)$ & $2.54(55.60)$ \\
\hline $\mathrm{T} 7\left(220^{\circ} \mathrm{C} / 30 \mathrm{~min}\right)$ & $6.74(60.01)$ & $10.09(35.69)$ & $2.21(61.36)$ \\
\hline $\mathrm{T} 8\left(220^{\circ} \mathrm{C} / 60 \mathrm{~min}\right)$ & $5.71(69.51)$ & $5.96(62.01)$ & $1.66(70.98)$ \\
\hline $\mathrm{T} 9\left(220^{\circ} \mathrm{C} / 90 \mathrm{~min}\right)$ & $4.37(76.67)$ & $4.78(69.53)$ & $1.08(81.12)$ \\
\hline $\mathrm{Middle} \mathrm{Portion}$ & & & \\
\hline $\mathrm{Control} \mathrm{samples}$ & 18.24 & 14.27 & 5.22 \\
\hline $\mathrm{T} 1\left(180^{\circ} \mathrm{C} / 30 \mathrm{~min}\right)$ & $14.59(20.01)$ & $12.69(11.07)$ & $4.41(15.52)$ \\
\hline $\mathrm{T} 2\left(180^{\circ} \mathrm{C} / 60 \mathrm{~min}\right)$ & $11.67(36.02)$ & $8.86(37.91)$ & $3.79(27.40)$ \\
\hline $\mathrm{T} 3\left(180^{\circ} \mathrm{C} / 90 \mathrm{~min}\right)$ & $8.98(50.77)$ & $4.48(68.61)$ & $3.23(38.12)$ \\
\hline $\mathrm{T} 4\left(200^{\circ} \mathrm{C} / 30 \mathrm{~min}\right)$ & $9.09(50.16)$ & $8.79(38.40)$ & $3.08(41.00)$ \\
\hline $\mathrm{T} 5\left(200^{\circ} \mathrm{C} / 60 \mathrm{~min}\right)$ & $8.49(53.45)$ & $5.68(60.20)$ & $2.56(50.96)$ \\
\hline $\mathrm{T} 6\left(200^{\circ} \mathrm{C} / 90 \mathrm{~min}\right)$ & $6.80(62.72)$ & $5.52(61.32)$ & $2.51(51.92)$ \\
\hline $\mathrm{T} 7\left(220^{\circ} \mathrm{C} / 30 \mathrm{~min}\right)$ & $7.08(61.18)$ & $7.94(44.36)$ & $2.83(45.79)$ \\
\hline $\mathrm{T} 8\left(220^{\circ} \mathrm{C} / 60 \mathrm{~min}\right)$ & $7.41(59.30)$ & $6.75(52.70)$ & $1.81(65.33)$ \\
\hline $\mathrm{T} 9\left(220^{\circ} \mathrm{C} / 90 \mathrm{~min}\right)$ & $5.74(68.53)$ & $3.10(78.28)$ & $0.91(82.57)$ \\
\hline $\mathrm{B}$ ttom $\mathrm{Portion}$ & & & \\
\hline $\mathrm{Control} \mathrm{samples}$ & 10.53 & 11.48 & 5.02 \\
\hline $\mathrm{T} 1\left(180^{\circ} \mathrm{C} / 30 \mathrm{~min}\right)$ & $10.18(3.32)$ & $10.19(11.24)$ & $4.55(9.36)$ \\
\hline $\mathrm{T} 2\left(180^{\circ} \mathrm{C} / 60 \mathrm{~min}\right)$ & $9.30(11.68)$ & $6.31(45.03)$ & $3.91(22.11)$ \\
\hline $\mathrm{T} 3\left(180^{\circ} \mathrm{C} / 90 \mathrm{~min}\right)$ & $8.28(21.37)$ & $4.21(63.33)$ & $2.73(45.62)$ \\
\hline $\mathrm{T} 4\left(200^{\circ} \mathrm{C} / 30 \mathrm{~min}\right)$ & $9.18(12.82)$ & $6.83(40.51)$ & $2.76(45.02)$ \\
\hline $\mathrm{T} 5\left(200^{\circ} \mathrm{C} / 60 \mathrm{~min}\right)$ & $7.35(30.20)$ & $5.81(49.39)$ & $1.71(65.94)$ \\
\hline $\mathrm{T} 6\left(200^{\circ} \mathrm{C} / 90 \mathrm{~min}\right)$ & $4.24(59.73)$ & $4.87(57.58)$ & $1.11(77.89)$ \\
\hline $\mathrm{T} 7\left(220^{\circ} \mathrm{C} / 30 \mathrm{~min}\right)$ & $7.67(27.16)$ & $7.87(31.45)$ & $1.36(72.91)$ \\
\hline $\mathrm{T} 8\left(220^{\circ} \mathrm{C} / 60 \mathrm{~min}\right)$ & $4.65(55.84)$ & $7.00(39.02)$ & $0.66(86.85)$ \\
\hline $\mathrm{T} 9\left(220^{\circ} \mathrm{C} / 90 \mathrm{~min}\right)$ & $3.71(64.77)$ & $1.87(83.71)$ & $0.54989 .24)$ \\
\hline $\mathrm{N})$ & & \\
\hline
\end{tabular}

Note: ()$=\%$ change from control 
As the woods undergo the oil-heat treatment, the moisture content of the wood is decreasing. Moisture is the key ingredient for all types of biological damage of wood [17]. So, due to this condition, the fungi attack also fall because fungi need the moisture to attack the wood [15]. Active decay fungi attack could be stopped by removing the moisture since fungi become dormant when moisture content decrease below than $20 \%$ and the sorption of water into material limited because of the increased of hydrophobic character of wood which is not favorable to the growth of fungi $[18,19]$.

\section{Analysis of Variance and Correlation Analysis on Durability of treated $A$. mangium}

Table 3 shows the analysis of variance (ANOVA) for physical of A. mangium. The analysis was conducted to determine whether there was a significance difference between the durability of wood with treatment temperatures, duration, and portion. Based on the table, there were significant differences between weight loss with the treatment temperatures $\left(180^{\circ} \mathrm{C}, 200^{\circ} \mathrm{C}, 220^{\circ} \mathrm{C}\right)$ as a factor. These means that temperature of the treatment is affected the durability of $A$. mangium wood. As the duration of the treatment also affecting the strength of wood that studied in this research. While Table 4 highlighted that the correlation analysis of weight loss in oil heat treatment of Acacia mangium.

The wood height consisting of three portions shows a significant difference between weight loss and the portions. There is also a significant difference for the fungi variables which include three types of fungi. These outcomes also supported by research carried out by Razak et al. [1].

Table 3: ANOVA of durability of A. mangium.

\begin{tabular}{|l|l|l|l|l|}
\hline S.V. & Sum of Squares & Df & Mean Square & F-Ratio \\
\hline Temperature & 678.676 & 2 & 333.338 & $20.534^{*}$ \\
\hline Duration & 352.425 & 2 & 176.212 & $9.852^{*}$ \\
\hline Fungi & 1994.747 & 2 & 997.374 & $90.325^{*}$ \\
\hline Portion & 413.478 & 2 & 206.726 & $11.726^{*}$ \\
\hline
\end{tabular}

$* *$ significant at $\mathrm{p} \leq 0.01, *=$ significant at $\mathrm{p} \leq 0.05, \mathrm{~ns}=$ not significant. 
Prime Archives in Agricultural Research

Table 4: Correlation analysis of weight loss in the oil heat treatment of $A$. mangium.

\begin{tabular}{|l|l|l|l|l|l|l|}
\hline & Portion & Density & Temp. & Duration & Fungi & Weight Loss \\
\hline Portion & 1.0000 & $5.0038 \mathrm{e}-001$ & 0.0000 & 0.0000 & $0.0000 \mathrm{e}+00$ & 0.2945 \\
\hline Density & & 1.0000 & -0.2723 & -0.4117 & $-9.3762 \mathrm{e}-018$ & 0.0931 \\
\hline Temperature & & & 1.0000 & 0.0000 & $0.0000 \mathrm{e}+00$ & 0.3822 \\
\hline Duration & & & & 1.0000 & $0.0000 \mathrm{e}+00$ & 0.2754 \\
\hline Fungi & & & & & 1.0000 & 0.6215 \\
\hline Weight Loss & & & & & & 1.0000 \\
\hline
\end{tabular}

\section{Micromorphology of Colonized A. mangium}

The micromorphology of the oil heat treatment of 18-year-old $A$. mangium wood observed to detect changes occurred before and after being exposed to the fungi. Observations made by using the Scanning Electron Microscope. The vessels structure were focussed into since they were the primary structure found in the wood for observation between untreated and treated wood. Figure 5 showed the images of untreated and treated A. mangium that being exposed to the $P$. sanguineus.
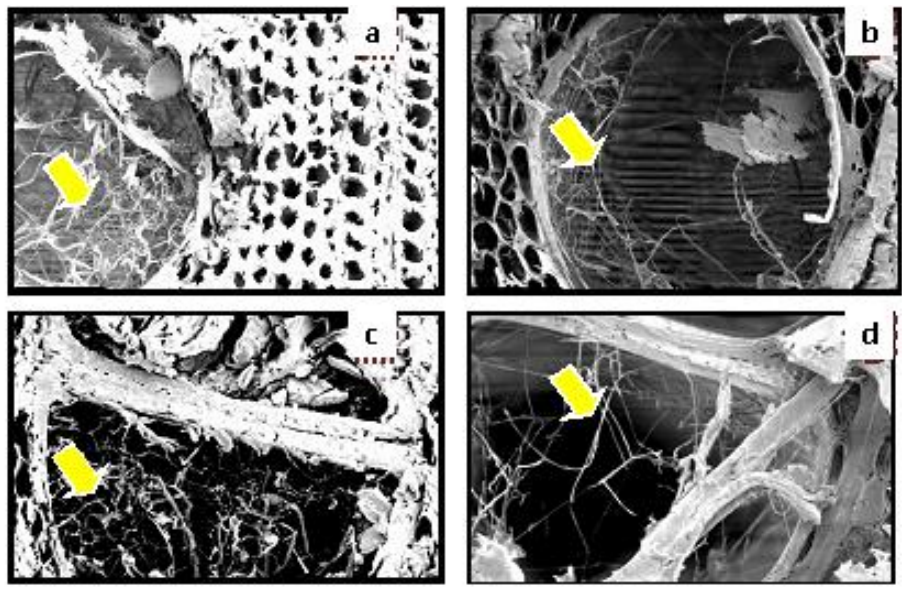

Figure 5: SEM images (transverse sections) of Acacia mangium woods sampled colonized by $P$. sanguineus after 12 weeks incubation period. A more prolific mycelia (arrows) permeating and filling the lumen of vessels of untreated wood $(\mathrm{a}, \mathrm{c})$ was observed as compared to wood experienced Treatment $9(b, d)$. 
Prime Archives in Agricultural Research
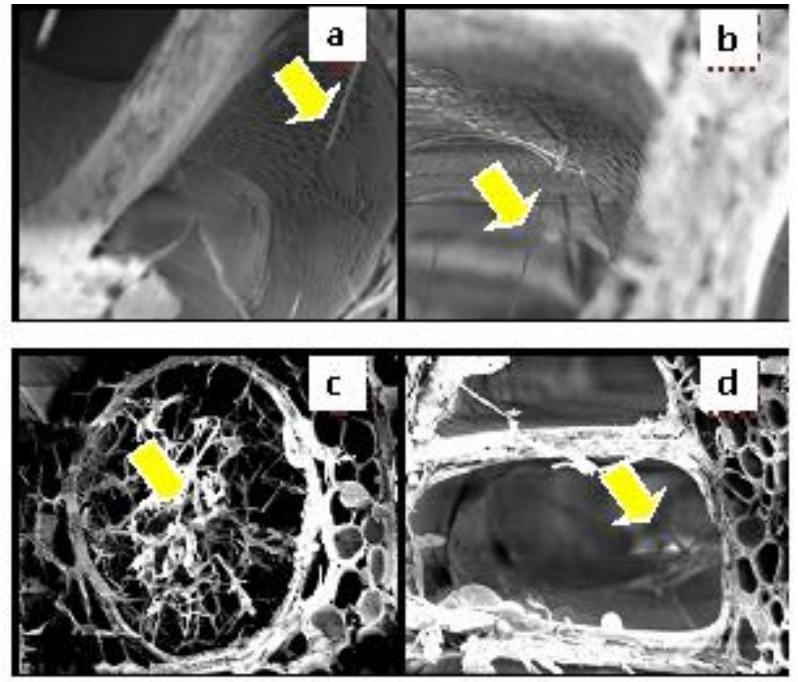

Figure 6: SEM images (transverse sections) of Acacia mangium woods sampled colonized by $C$. versicolor after 12 weeks incubation period. More prolific mycelia (arrows) permeating and filling the lumen of vessels of untreated wood $(\mathrm{a}, \mathrm{c})$ was observed as compared to wood experienced Treatment 9 (b, d).
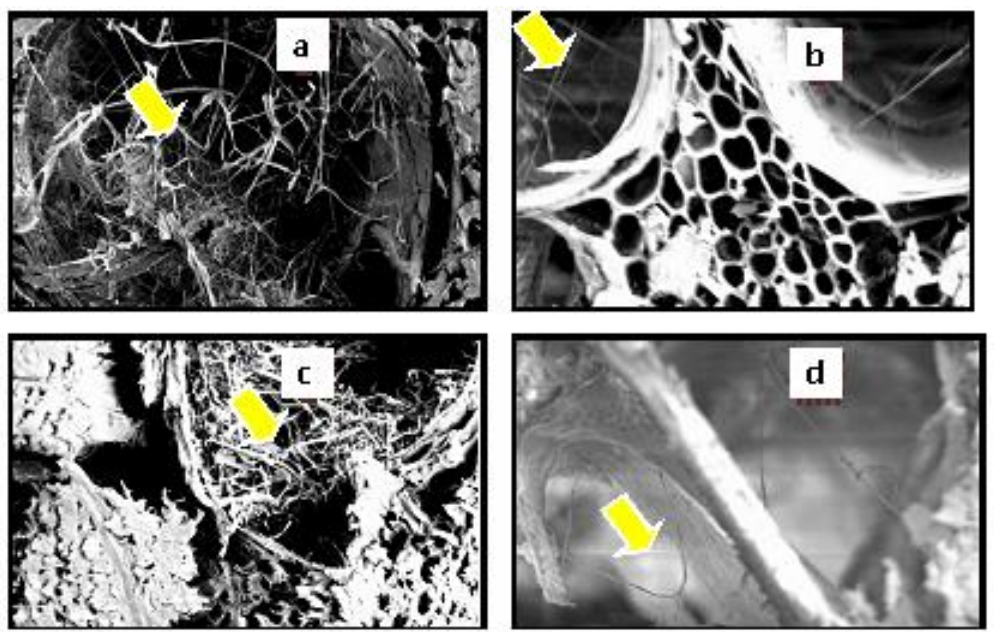

Figure 7: SEM images (transverse sections) of Acacia mangium woods sampled colonized by $G$. trabeum after 12 weeks incubation period. More prolific mycelia (arrows) permeating and filling the lumen of vessels of untreated wood $(\mathrm{a}, \mathrm{c})$ was observed as compared to wood experienced Treatment $9(b, d)$. 
The wood treated at $220^{\circ} \mathrm{C}$ for 90 minutes shows the less colonization of mycelia compared with the untreated wood. The samples exposed to the fungi for 12 weeks. The same pattern of results also obtained for the wood that exposed to the $C$. versicolor (Figure 6) and G. trabeum (Figure 7). From the images, it can seem that there were changes that occur after the wood samples treated by using the oil-heat treatment. The untreated A. mangium wood shows the massive colonization of mycelia within the wood vessel compared with the treated wood. These showed that the oil-heat treatment had affected the structure of wood.

The oil heat-treated wood experience changes in structure. Modification of the cell wall structure, causing the deformation of the wood cells, especially the vessels. Razak et al., [14] also came out with the same pattern of results where hyphae and mycelia could observe within all cell types such as vessels, fibres and parenchyma. Vessels were the most resistant elements apparently to degradation by fungi. The factor of the massive colonization of mycelia in untreated samples compared with oilheat treated was because during oil-heat treatment process the hydrophobic character of wood has increased which caused limited sorption of water into the material and not favourable to the growth fungi [19].

\section{Conclusions}

The oil heat treatment process increases the densities of the treated A. mangium. The densities increase from the bottom to the top portion of the tree. The oil-heat treatment increased the durability of $A$. mangium wood.

The attack of G. trabeum reduced from $0.54 \%-4.55 \%$ at top, middle and bottom, respectively. The $C$. versicolor attacks reduced from $4.78 \%-15.20 \%, 3.10 \%-12.69 \%$, and $1.87 \%$ $10.19 \%$ at the top, middle and bottom portions, while the $P$. sanguineus attacks from $3.71 \%-10.18 \%, 5.74 \%-14.59 \%$, and $4.37 \%-17.08 \%$ at the bottom, middle, and top portions. 
For effective treatment, it is recommended to apply a temperature of $200^{\circ} \mathrm{C}$ to $220^{\circ} \mathrm{C}$ and duration between 60 to 90 minutes for enhancing the durability of the A. mangium wood.

\section{References}

1. Razak W, Othman S, Aminudin M, Tamer AT, Farah WA. Durability Assessment of Oil Heat Treated 15-Year-old Cultivated Acacia hybrid Inoculated with Coriolus versicolor, Gloeophyllum trabeum and Pycnoporus sanguineus. Journal of Agricultural Science. Canadian Center for Science and Education. 2010; 2.

2. Tuong VM, Li J. Effect of heat treatment on the change in color and dimensional stability of Acacia hybrid wood. BioResources. 2010; 5: 1257-1267.

3. Esteves BM, Pereira HM. Wood modification by heat: A review. BioResources, 4(1), 370-404. Journal of Progress in Polymer Science. 2009; 24: 221-274.

4. Homan WJ, Jorissen AJM. Wood modification developments. HERON. 2004; 49: 361-386.

5. Izyan K, Razak W, Othman S, Aminuddin M, Hanim RA. Enhancing colour appearances of cultivated 15-year-old Acacia hybrid through the oil heat treatment process. International Journal of Biology. Canadian Center for Science and Education. 2010; 2: 199-209.

6. Razak W, Izyan K, Roziela H, Othman S, Aminuddin M. Effects of hot oil treatment on colour and chemical changes in year-old cultivated Acacia hybrid. Journal of Tropical Forest Science (JTFS). 2011; 23: 42-50.

7. Izran K, Razak W, Zaidon A, Abood F, Norhisham AR. The effects of oil boiling treatment on physical properties of Bambusa vulgaris var. Striata (Buluh Gading). PERTANIKA Journal of Tropical Science. 2011; 35: 833-844.

8. Rafidah MD. Effect of high temperature boiling on properties of Gigantochloa scortechnii Gamble (Buluh Semantan). Master Thesis. Universiti Putra Malaysia, Malaysia. 2007.

9. Razak W, Aminudin M, Hashim WS, Othman S. Effect of Heat Treatment Using Palm Oil on Properties and Durability of Semantan Bamboo. Journal of Rattan and Bamboo. 
International Network for Bamboo and Rattan. 2005; 4: 211220.

10. AWPA. The standard method of testing wood preservatives by laboratory soil-block cultures. M10-77. Wood Stock: American Wood-preservers, Association. 1989.

11. Razak W, Hashim WS, Othman S, Rafidah S, Rokiah H. Properties of Oil-cured Cultivated Bambusa vulgaris. International Journal of Agricultural Research. 2007; 2: 820825.

12. Li X. Physical, Chemical, and Mechanical Properties of Bamboo and Its Utilization Potential for Fiberboard Manufacturing. Master of Science. Louisiana State University, Los Angeles. 2004.

13. Razak W, Hashim W, Othman S. The Rattan Processing and Transformation Industry in Malaysia. Published by Universiti Malaysia Sabah. 2010.

14. Razak W. Enhancing finished products appearances and durability of sapwood from cultivated Acacia hybrid and Tectona grandis through environmental friendly heat treatment process. Project Report on Science Fund (SCF0037-IND-1/2007). 2010.

15. Shmulsky R, Jones PD. Forest Products and Wood Sciences: An Introduction. Sixth Edition. New Jersey: John Wiley \& Sons, Inc. Publications. 2011.

16. Rowell RM. Handbook of wood chemical and wood composites. Madison. Florida: CRC Press. 2005.

17. Clausen CA. Recognize, Remove and Remediate Mold and Mildew. In: Proceedings of the Second Annual Conference on Durability and Disaster Mitigation in Wood Frame Housing. Forest Products Society. 2002; 231-234.

18. Sandra LB, Micheal LR. Plant Water Relations and the Fiber Saturation Point. New Phytologist. 2005; 168: 25-37.

19. Weiland J, Guyonnet R. Study of chemical modifications and fungi degradation of heat modified wood using DRIFT spectroscopy. Holz als Roh- und Wekstoff. 2003; 61: 216220. 